\title{
56
}

\section{PERKEMBANGAN PERILAKU KEPRIBADIAN REMAJA DENGAN LATAR BELAKANG KEDUA ORANG TUA BERCERAI}

\author{
Oleh: \\ Aziza Trizilvania Amadea, Santoso Tri Raharjo, \& Budi M. Taftazani
}

Email:

azizatrizilvania@gmail.com; santosotriraharjo@gmail.com; budi.m.taftazani@yahoo.com

\begin{abstract}
ABSTRAK
Dampak perceraian orang tua terhadap perilaku anak merupakan akibat dari perceraian yang membuat perilaku anak mengalami kemorosotan antara lain mengalami depresi, menkonsumsi alkohol, aktifitas seksual dini (pemerkosaan), menjadi keras kepala, sering minum mabok, mengganggu ketenangan tetangga, anak menjadi rendah diri. Hal tersebut perlu diperhatikan terutama ketika pelaku perceraian yang memiliki anak remaja. Dikarenakan remaja merupakan masa penuh kegoncangan, taraf mencari identitas diri dan merupakan periode yang paling berat. Adanya akibat yang langsung terhadap sikap dan tingkah laku serta akibat-akibat jangka panjangnya menjadikan periode remaja lebih penting daripada periode lainya.Selain itu perkembangan fisik yang cepat dan penting disertai dengan cepatnya perkembangan mental, terutama pada awal remaja, yang semua perkembangan itu menimbulkan perlunya penyesuaian mental dan membentuk sikap, nilai dan minat baru.
\end{abstract}

Kata kunci : Perkembangan perilaku remaja, dampak perceraian bagi remaja.

\section{PENDAHULUAN}

Menurut data yang dikeluarkan oleh pengadilan agama Kota Bandung pada tahun 2011tercatat bahwa angka perceraian yang terjadi di Kota Bandung meningkat. Data per November 2011 kasus percerain yang masuk ke pengadilan mencapai 3.795 perkara, sedangkan sepanjang tahun 2010 sebanyak 2.629 perkara. Permasalah yang terjadi akibat perceraian tidak hanya melibatkan kedua belah pihak saja yaitu seorang istri dan suami melainkan orang terdekat yang melakukan perceraian tersebut. Salah satu contohnya jika kedua pasangan tersebut telah memiliki anak dalam penikahan mereka. Maka perceraian tersebut juga akan membawa dampak terhadap anak yang mereka miliki. Terlebihlagi ketika anak tersebut menginjak usia remaja, dimana usia remaja merupakan usia pencarian jati diri dalam hidupnya. Dalam usia remaja inilah seorang anak butuh didampingi oleh kedua orangtuanya. Peran orang tua pada masa perkembangan remaja adalah sebagai panutan bagi perkembangan remaja terutama pada perkembangan psikis dan emosi, karena orang tua merupakan pendorong pembentukan karakter yang terdekat. Jika remaja dihadapkan pada kondisi orang tua bercerai, dimana orang tua mereka tidak lagi menjadi panutan bagi dirinya maka akan berdampak besar pada perkembangan dirinya. Dampak psikis yang dialami oleh remaja dengan orang tua bercerai, remaja menjadi lebih pendiam, pemalu, bahkan depresi berkepanjangan. Karena dampak seperti itulah yang membantu terbentukanya perilaku remaja.

Selain dampak dampak negatif yang bakal terjadi terhadap perilaku perkembangan remaja, tidak menutup kemungkinan dari perceraian ini menimbulkan dampak positif juga bagi perilaku perkembangan bagi remaja. Contohnya pada saat remaja dihadapkan oleh situasi kedua orang tuanya 
yang bercerai, maka timbulnya motivasi dalam dirinya agar kelak kehidupannya di masa depan tidak "gagal" seperti orang tuanya. Selain itu dikarenakan pandangan masyarakat pada umumnya menganggap bahwa anak yang berasal dari keluarga dari kedua orang tua yang bercerai sering dipandang negatif, hal tersebut bisa menjadi acuan remaja untuk menunjukkan kepada masyarakat bahwa anak yang berasal dari kedua orang tua yang bercerai pun tidak selamanya berperilaku negatif.

Dari kemungkinan dampak yang terjadi itulah maka perceraian yang dialami oleh orang tuanya menjadi faktor pembentuk perilaku perkembangan remaja. Orang tua berperan penting dalam perilaku remaja, baik yang bersifat positif maupun negatif. Hal ini pula menunjukkan bahwa orang tua masih merupakan lingkungan yang sangat penting bagi remaja. Namun sebagaimanapun hubungan orang tua dan remaja begitu baik, tetap saja dengan adanya masalah yang timbul dalam keluarga itu sendiri terutama masalah antara ibu dan ayah yaitu salah satunya perceraian, maka mau tidak mau anak secara tidak langsung akan menjadi korbannya dan sangat berakibat fatal bagi perkembangan kepribadian remaja.

Banyak fenomena - fenomena yang terjadi bahwa anak yang diasuh satu orang tua akan jauh lebih baik dari pada anak yang diasuh keluarga untuh yang dipenuhi dengan rasa tertekan. Perceraian dalam keluarga tidaklah selalu membawa dampak negatif. Perbedaan paham yang terus - menerus, maka peristiwa perceraian itu satu - satunya jalan keluar untuk memperolah ketentraman diri. Bagaimana remaja bereaksi terhadap perceraian orang tuanya sangat dipengaruhi oleh cara orang tua berprilaku, selama dan sesudah perpisahan. Remaja akan membutuhkan dukungan, kepekaan, dan kasih sanyang yang lebih besar untuk membantunya mengatasi kehilangan yang dialami selama masa sulit ini. Mereka mungkin akan menunjukkan kesulitan penyesuaian diri dalam bentuk maslah perilaku, kesulitan belajar, atau penarikan diri dari lingkungan sosial.

Perkembangan perilaku merupakan hal yang penting bagi masa depan remaja untuk menuju tahap dewasa anak. Maka dari itu penelitian ini penting dilakukan untuk melihat perkembangan perilaku remaja yang dilantar belakangi oleh kedua orang tua bercerai.

Terbentuknya perilaku dapat terjadi karena proses kematangan dan dari proses interaksi dengan lingkungan. Terbentuknya dan perubahan perilaku karena proses interaksi antara individu dengan lingkungan ini melalui suatu proses yakni proses belajar. Oleh sebab itu, perubahan perilaku dan proses belajar sangat erat kaitannya. Perubahan perilaku merupakan hasil dari proses belajar.

Di dalam proses pembentukan atau perubahan perilaku yang di hasilkan melalui indera penglihatan, pendengaran, penciuman dan lain sebagainya. Sedangkan motovasi diartikan sebagai dorongan untuk bertindak untuk mencapai suatu tujuan tertentu. Hasil dari dorongan gerakan inilah yang diwujudkan dalam bentuk perilaku. Perilaku yang berlaku pada individu atau organisme tidak timbul dengan sendirinya. Tetapi sebagai akibat dari stimulus yang diterima oleh organisme yang bersangkutan. Baik itu stimulus eksternal maupun stimulus internal (Walgito, 1991).

Didalam teori perkembangan perilaku terdapat teori kognitif yang dekat dengan pembahasan yang akan dibahas oleh peneliti. Berikut adalah penjelasannya:

Menurut Piaget, perkembangan kognitif mempunyai empat aspek, yaitu 1) kematangan, sebagai hasil perkembangan susunan syaraf; 2) pengalaman, yaitu hubungan timbal balik antara orgnisme dengan dunianya; 3) interaksi sosial, yaitu pengaruh-pengaruh yang diperoleh dalam hubungannya dengan lingkungan sosial, dan 4) ekuilibrasi, yaitu adanya kemampuan atau sistem mengatur dalam diri organisme agar dia selalu mempau mempertahankan keseimbangan dan penyesuaian diri terhadap lingkungannya.

\section{a. Kematangan}

Kematangan system syaraf menjadi penting karena memungkinkan anak memperoleh manfaat secara maksimum dari pengalaman fisik. Kematangan membuka kemungkinan untuk perkembangan sedangkan kalau kurang hal itu akan membatasi secara luas prestasi secara kognitif. Perkembangan berlangsung dengan kecepatan yang berlainan tergantung pada sifat kontak dengan lingkungan dan kegiatan belajar sendiri. 


\section{b. Pengalaman}

Interaksi antara individu dan dunia luar merupakan sumber pengetahuan baru, tetapi kontak dengan dunia fisik itu tidak cukup untuk mengembangkan pengetahuan kecuali jika intelegens iindividu dapat memanfaatkan pengalamantersebut.

c. InteraksiSosial

Lingkungan social termasuk peran bahasa dan pendidikan, pengalaman fisik dapat memacu atau menghambat perkembangan struktur kognitif

d. Ekuilibrasi

Proses pengaturan diri dan pengoreksi diri (ekuilibrasi), mengatur interaksi spesifik dari individu dengan lingkungan maupun pengalaman fisik, pengalaman social dan perkembangan jasmani yang menyebabkan perkembangan kognitif berjalan secara terpadu dan tersusun baik.

Dalam pandangan Piaget, anak-anak secara aktif membangun dunia kognitif mereka dengan menggunakan skema untuk menjelaskan hal-hal yang mereka alami. Skema adalah struktur kognitif yang digunakan oleh manusia untuk mengadaptasi diri terhadap lingkungan dan menata lingkungan ini secara intelektual. Piaget (1952) mengatakan bahwa ada dua proses yang bertanggung jawab atas seseorang menggunakan dan mengadaptasi skema mereka:

1. Asimilasi adalah proses menambahkan informasi baru ke dalam skema yang sudah ada. Proses ini bersifat subjektif, karena seseorang akan cenderung memodifikasi pengalaman atau informasi yang diperolehnya agar bias masuk ke dalam skema yang sudah ada sebelumnya.

2. Akomodasi adalah bentuk penyesuaian lain yang melibatkan pengubahan atau penggantian skemaakibatadanyainformasibaru yang tidaksesuaidenganskema yang sudahada. Dalam proses inidapat pula terjadipemunculanskema yang barusamasekali.

\section{PerkembanganPerilakuRemajadalamPerspektifPekerjaanSosial}

Pekerjaan social merupakan bidang keahlian yang memiliki kewenangan untuk melaksanakan berbagai upaya guna meningkatkan kemampuan orang dalam melaksanakan fungsi-fungsi sosialnya melalui proses interaksi, agar orang dapat menyesuaikan diri dengan situasi kehidupannya secara memuaskan, Skidmore dan Thackeray dalam (Wibhawa, 2010:42). Pernyataan tersebut didukung dengan pernyataan yang diungkapkan oleh Edi Suharto (2009) mengenai definisi pekerjaansosial:

Pekerjaan Sosial adalah aktivitas professional untuk menolong individu, kelompok dan masyarakat dalam meningkatkan atau memperbaiki kapasistas mereka agar berfungsi social dan menciptakan kondisi-kondisi masyarakat yang kondusif untuk mencapai tujuan tersebut. (Suharto, 2009:1)

Salah satu yang menjadi bidang garapan pekerja sosial di dalam perkembangan perilaku remaja adalah dengan cara pendampingan. Pekerja sosial perlu memahami siapa yang menjadi fokus utama dari pekerjaannya atau intervensinya, apakah anak atau keluarga. Kesejahteraan anak merupakan fokus yang terpenting, namun untuk mencapai hasil tersebut pekerja sosial juga perlu bekerja dengan keluarga. Sebagai seorang profesional pekerja sosial harus berkomitmen untuk standar-standar perilaku tertentu dan memberikan pelayanan dengan baik ke pada anak dan keluarga yang menggunakan jasanya.Selain itu, pekerja sosial yang bekerja dengan anak dan keluarga perlu mengerti mengenai nilai-nilai serta kode etik, serta perlu menyadari bahwa setiap keluarga itu berbeda-beda dan harus mampu menilai manfaat yang dapat diambil dari permasalahan keluarga yang mereka hadapi.Terdapat enam poin utama dalam kode etik tersebut dalam O'Loughlin (2008:6-7):

1. Melindungi dan meningkatkan hak-hak serta kepentingan klien.

2. Mengupayakan untuk membangun dan memelihara kepercayaan dan keyakinan dari klien.

3. Meningkatkan kemandirian dan melindungi klien dari hal-hal yang membahayakan. 
4. Menghormati hak-hak klien dan memastikan bahwa tindakan yang mereka lakukan tidak membahayakan diri sendiri dan orang lain.

5. Menjunjung tinggi kepercayaan dan keyakinan dalam memberikan pelayanan.

6. Bertanggungjawab atas kualitas dari pekerjaan yang dilakukan dan memiliki tanggung jawab untuk memelihara dan meningkatkan pengetahuan dan keterampilannya.

Ketika melakukan intervensi, pekerjasosial perlu mengetahui aspek pengasuhan yang penting untuk mencapai tahap perkembangan dan mengembangkan potensi anak. Daniel dalam (O'Loughlin, 2008:69) mengatakan bahwa terdapat tugas-tugas dalam pengasuhan anak dalam kelompok usia yang berbeda, hal tersebut dapat membantu pekerja sosial dalam melakukan intervensi dengan orang tua untuk meningkatkan kapasitas orang tua dalam pengasuha nanak.

AdapuntujuanProfesiPekerjaanSosialyaitu :

1. Meningkatkan kapasitas orang dalam mengatasi masalah yang dihadapinya. Dalam menjalankan peran ini, Pekerja Sosial mengidentifikasi hambatan-hambatan klien dalam melaksanakan tugastugas kehidupannya. Pekerja sosial juga menggali kekuatan-kekuatan yang ada pada diri klien guna mengembangkan solusi dan rencana pertolongan.

2. Menggali dan menghubungkan sumber-sumber yang tersedia di sekitar klien. Beberapa tugas Pekerja Sosial yang terkait dengan peran ini antara lain: a) Membantu klien menjangkau klienklien yang diperlukannya; b) Mengembangkan program pelayanan sosial yang mampu memberikan manfaat optimal bagi klien; c) Meningkatkan komunikasi diantara para petugas kemanusiaan; dan d) Mengatasi hambatan-hambatan dalam proses pelayanan sosial bagi klien.

3. Meningkatkan jaringan pelayanan sosial. Tujuan utama dari peran ini adalah untuk menjamin bahwa sistem kesejahteraan sosial berjalan secara manusiawi, sensitif terhadap kebutuhan warga setempat dan efektif dalam memberikan pelayanan sosial terhadap masyarakat.

4. Mengoptimalkan keadaan sosial melalui pengembangan kebijakan sosial. Dalam menjalankan peran ini, Pekerja sosial mengidentifikasi isu-isu sosial dan implikasinya bagi kehidupan masyarakat. Kemudian, Pekerja Sosial membuat naskah kebijakan (policy paper) yang memuat rekomendasi-rekomendasi bagi pengembangan kebijakan-kebijakan baru maupun perbaikan dan pergantian kebijakan-kebijakan lama yang tidak berjalan efektif. Selain itu, dalam melaksanakan peran ini, Pekerja Sosial juga dapat menterjemahkan kebijakan-kebijakan publik ke dalam program dan pelayanan sosial yang dibutuhkan klien. (Dubois dan Miley dalam Wibhawa, 2010:50)

\begin{tabular}{|c|c|c|}
\hline No & Sub Topik & Aspek yang mempengaruhi \\
\hline 1 & $\begin{array}{l}\text { Kematangan sebagai hasil } \\
\text { perkembangan susunan syaraf }\end{array}$ & $\begin{array}{l}\text { - Manfaat yang di peroleh dari } \\
\text { perkembangan fisik } \\
\text { - Bentuk adaptasi dari perubahan fisik } \\
\text { yang mempengaruhi individu } \\
\text { terhadap lingkungannya }\end{array}$ \\
\hline 2 & $\begin{array}{l}\text { Pengalaman sebagai hubungan } \\
\text { timbal balik antara remaja } \\
\text { dengan dunianya }\end{array}$ & $\begin{array}{l}\text { - } \text { Aktualisasi diri terhadap lingkungan } \\
\text { - Manfaat yang di dapat dari } \\
\text { pengalaman yang terjadi pada remaja }\end{array}$ \\
\hline 3 & $\begin{array}{l}\text { Interaksi social sebagai } \\
\text { pengaruh yang diperoleh dalam } \\
\text { hubungan sosial }\end{array}$ & $\begin{array}{l}\text { - Manfaat yang terjadi akibat adanya } \\
\text { interaksi sosial } \\
\text { - Perubahan yang terjadi akibat adanya } \\
\text { interaksi sosial }\end{array}$ \\
\hline
\end{tabular}




\begin{tabular}{|l|l|llll|}
\hline 4 & $\begin{array}{l}\text { Ekuilibrasi sebagai kemampuan } \\
\text { atau sistem yang mengatur } \\
\text { remaja dalam menyesuaikan diri } \\
\text { dengan lingkungan }\end{array}$ & $-\begin{array}{l}\text { Bentuk pengaturan } \\
\text { interaksi sosial }\end{array}$ & $\begin{array}{l}\text { Bentuk pengaturan } \\
\text { perkembangan fisik }\end{array}$ & diri & dengan \\
\hline
\end{tabular}

\section{Simpulan}

Perkembangan remaja yang memiliki orang tua bercerai akan berdampak pada remaja yang merupakan individu yang masih menentukan jati dirinya. Oleh karena itu remaja sangat membutuhkan sosok seseorang yang dapat memberikan pengetahuan atau contoh tentang pelajaran hidupnya. Dikarenakan orang tua berperan penting dalam perilaku remaja, baik yang bersifat positif maupun negatif. Hal ini pula menunjukkan bahwa orang tua masih merupakan lingkungan yang sangat penting bagi remaja. Namun sebagaimanapun hubungan orang tua dan remaja begitu baik, tetap saja dengan adanya masalah yang timbul dalam keluarga itu sendiri terutama masalah antara ibu dan ayah yaitu salah satunya perceraian, maka mau tidak mau anak secara tidak langsung akan menjadi korbannya dan sangat berakibat fatal bagi perkembangan kepribadian remaja.

Saran

Setelah melakukan penelitian ini, peneliti menyarankan kepada kedua orang tua yang bercerai yang memiliki anak remaja dapat diharapkan untuk terus berperan aktif dalam menjaga dan memberikan pembinaan kepada anaknya meskipun ayah dan ibunya sudah berpisah dan tidak tinggal di satu rumah lagi. Hal tersebut merupakan hal yang penting bagi tumbuh kembang anak, apalagi anak yang sedang berada di fase remaja. Fase dimana anak melakukan pencarian jatidiri, oleh karena itu peran kedua orang tua tetap sangat dibutuhkan. Dengan penelitian ini pula diharapkan orang tua yang bercerai dan memiliki anak bisa mengantisipasi untuk tidak terjadinya perlakuan negatif yang dilakukan oleh remaja dengan bantuan pengawasan dan perhatian dari orang tuanya. 